\title{
Temporal variation of currents, particulate flux and organism supply at two deep-sea hydrothermal fields of the Azores Triple Junction
}

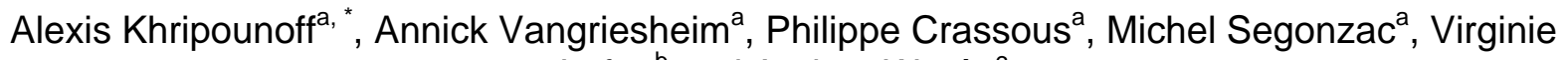 \\ Lafon $^{\mathrm{b}}$ and Anders Warén ${ }^{\mathrm{c}}$ \\ a Ifremer, DEEP/LEP, BP70, 29280 Plouzané, France
b IMAR/DOP, Universidade dos Açores, 9901-862 Horta (Azores), Portugal
c Department of Invertebrate Zoology, Swedish Museum of Natural History, Box 5007, SE-10405 Stockolm,
Sweden
}

*: Corresponding author : Alexis Khripounoff, email address : Alexis.Khripounoff@ifremer.fr

\begin{abstract}
:
In order to provide information on the production and the distribution of hydrothermal particulate and biological material produced by deep-sea hydrothermal vents, three moorings with sediment traps and currentmeters were deployed for one year in the Azores Triple Junction region. Two moorings were positioned close to two hydrothermal vent fields at the Mid-Atlantic Ridge (Rainbow, $36^{\circ} 14^{\prime} \mathrm{N}$, $33^{\circ} 54^{\prime} \mathrm{W}, 2250 \mathrm{~m}$ depth and Lucky Strike $37^{\circ} 17^{\prime} \mathrm{N}, 32^{\circ} 17^{\prime} \mathrm{W}, 1600 \mathrm{~m}$ depth). A third was moored out of the influence of the Rainbow vents representing the reference of the pelagic flux in this area. At the Rainbow field, particulate flux (range 341-634 g m-2 d-1) showed a high temporal variation controlled essentially by the current direction. The particles were characterized by a high concentration of total sulfur (16.4\%) and copper (8.6\%) and a low concentration of organic carbon (1.4\%). Bivalves collected in the trap belonged to the hydrothermal mytilid Bathymodiolus azoricus and were all in the prejuvenile prodissoconch II stage of their development. Their density decreased strongly between July and September, indicating a possible discontinuous reproduction of this species. The particles at Lucky Strike were rich in barium and the calculated flux was lower than at Rainbow (range 52-308 g m-2 $\mathrm{d}-1$ ) because of the translucent fluid poor in particles emitted at this shallower station. However, a peak in the flux was observed in May corresponding to the seasonal phytoplankton bloom. Two different bivalve species were sampled in this trap. The most abundant was B. azoricus. However, their development stages showed higher variations compared to the Rainbow trap. The abundance of mussels in the trap was very low throughout the year and does not allow one to show significant spawning periodicity.
\end{abstract}

Keywords: Deep-sea hydrothermal vents; Currents; Particle flux; Particle composition; Bivalve larvae; Bivalve reproduction; North Atlantic; Mid-Atlantic Ridge; Azores Triple Junction 


\section{Introduction}

Hydrothermal activity produces large amounts of mineral and biological material. The study of the hydrothermal system is now an important part of hydrothermal research because of the potential influence of the vent fluid on the ocean chemical balance and in order to tackle the question of the timing of reproduction in hydrothermal organisms. The production of the particulate material by vents and its dispersal in the deep ocean mostly depends on the emission of fluids that are precipitated as fine particles into the field and also carried by the neutrally buoyant hydrothermal plume. The discovery of deep-sea vents turned attention to sediments near vent fields on a wide-scale (Cave et al., 2002; German et al., 1999). Detailed observations have also been undertaken on the sedimentation from hydrothermal plumes (Dymond and Roth, 1988; Edmonds and German, 2004; Feely et al., 1994; German et al., 2002; Khripounoff et al., 2000). However, a gap remains in our knowledge of the initial production of material emitted by vents, and its temporal and composition variations. Only few trap experiments have been developed very close to vents and always of a short duration (Khripounoff and Alberic, 1991; Khripounoff et al., 2001). Hydrothermal activity also supports the production of biomass such as planktonic larval stages or juveniles of vent species (Mullineaux et al., 1995). These are carried by the near-bottom currents and/or the buoyant hydrothermal plume and are then transported several hundred meters above the bottom (Herring and Dixon, 1998; Kim et al., 1994; Mullineaux and France, 1995). However, a significant proportion of larvae must remain with the native habitat in order to maintain the local population assemblage on the scale of the vent field (Metaxas, 2004). An abundance of hydrothermal larvae close to the vents can be elevated (Mullineaux et al., 2005) and the nearbottom larval supply presents great temporal and spatial variations (Kim and Mullineaux, 1998; Metaxas, 2004). However, our understanding of the magnitude of larval retention around the hydrothermal field is limited.

The purpose of this study is to examine the composition and the flux of the settling hydrothermal particles emitted close to two active vents located at the Azores Triple Junction (ATJ). To provide information about the mineral and biological production of hydrothermal material, two moorings with sediment traps associated with current meters were deployed by the ROV Victor close to the Lucky Strike and Rainbow fields during one year. A third sediment trap was deployed at some distance away from the Rainbow hydrothermal source to obtain a measurement of the background pelagic flux to use as a reference for the Azores region. 


\section{Materials and methods}

\subsection{Study area}

Two sites were explored on the Mid-Atlantic Ridge (Fig. 1). The first was the

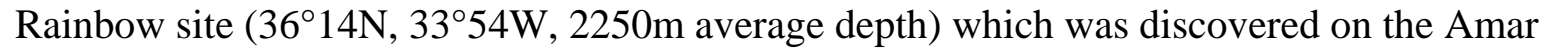
segment in 1997 (Fouquet et al., 1997). This is a very active hydrothermal field with about 10 major groups of extremely active black smokers without visible animals. A few diffusive vents are present not far from black smokers with mussels and shrimps.

The second was the Lucky Strike hydrothermal site $\left(37^{\circ} 17 \mathrm{~N}, 32^{\circ} 17 \mathrm{~W}, 1600 \mathrm{~m}\right.$ average depth) which was discovered at the Azores Triple Junction in 1993 (Langmuir et al., 1993). This area consists of a large central lava lake surrounded by three volcanic cones (Fouquet et al., 1994). The chemical description of the site was made by Colodner et al.(1993). Several translucent smokers were found on the volcano sides where mussels dominated and were distributed in patches of thousands of individuals (Desbruyères et al., 1994; Van Dover et al., 1996).

\subsection{Sampling}

Three moorings with sequential sediment traps associated with current meters were deployed in July 2001. The first was moored on the Rainbow site, the second $2 \mathrm{~km}$ to the East of the Rainbow field and the third on the Lucky Strike site during the Atos cruise. They were recovered in July 2002 during the Arquipelago cruise.

The settling particles were collected using cone-shaped traps (@Technicap PPS5) with 24 collection bottles. These traps had a sampling aperture of $1 \mathrm{~m}^{2}$ and were covered with a honeycomb baffle of $1 \mathrm{~cm}$ diameter and $10 \mathrm{~cm}$ deep cells at the top. Prior to deployment, the sampling bottles were filled with filtered seawater and sodium borate buffered formalin to give a final concentration of $3 \%$ in order to prevent in situ microbial decomposition. The sampling periods were 15 days each except for the last bottle (10 days).

traps close to vents by the ROV Victor. The trap unit consists of a PPS5 trap (as described above) modified by the addition of 8 syntactic foam floats (CEuroshore) to the structure of 
the equipment (Fig. 2a). In the final position, the trap aperture was $2.5 \mathrm{~m}$ above the bottom (a.b.).

One mooring (ML-1) with a trap of this design and an Aanderaa RCM8 current meter located 10 m above it (Fig. 2b), were deployed in July 2001 at the Rainbow vent field (N36² $13.784-\mathrm{W}^{\circ} 3^{\circ} 54.079,2250 \mathrm{~m}$ depth) situated $10 \mathrm{~m}$ to the North of the F5 station vent (Fig 1). Unfortunately, the trap worked for only 105 days and stopped in October. The mooring ML-3, a duplicate of the previous mooring, was deployed at the same date in the Lucky Strike vent field (N37¹7.539-W32¹6.404, 1620 m depth) 15 m from the Sintra vent. This trap worked for 360 days. A third mooring (ML-2, Pelagic) was positioned at $1550 \mathrm{~m}$ depth (N36 13.30 , W33 $^{\circ}$ 52.7) approximately at $2 \mathrm{~km}$ to the East of the Rainbow vents and represented the reference of the pelagic flux for the Azores region. It was composed of a standard PPS5 trap and a RCM 8 current meter at respectively $400 \mathrm{~m}$ and $410 \mathrm{~m}$ a.b. It worked for 360 days.

Aanderaa RCM 8 current-meters were equipped with a narrow range temperature channel (resolution: $0.006^{\circ} \mathrm{C}$ ) and a pressure sensor. The current and its direction, as well as temperature and pressure, were recorded once an hour. All the current, temperature and pressure sensors had been calibrated before and after the experiment in the calibration laboratory of Ifremer-Brest.

\subsection{Current data analysis}

The standard data processing, statistics (minimum, maximum, mean and variance) of current speed, East and North components, temperature, and pressure were done for the whole time series and also for a sub-series corresponding to the particle sampling dates (every 15 days). For each sub-series, histograms of temperature versus current direction were calculated in order to examine the influence of the nearby hot vents.

At Rainbow and Lucky Strike, the current speeds exceeded $15 \mathrm{~cm} / \mathrm{sec}$ by only less than $1 \%$, ensuring good conditions for the trap collection and thus good validity of the calculated mass fluxes.

\subsection{Primary production}

Primary production at Rainbow and Lucky Strike positions was calculated using satellite image data for April 2001- April 2003. Seastar/SeaWiFS 1.1 km resolution satellite images recorded at station HAZO were used in this study. The images were processed in the Department of Oceanography and Fisheries at the University of the Azores (IMAR-DOP/UA) 
using fully-automated imagery processes to compute Ocean Colour (OC) geophysical data (Figueiredo et al., 2004). OC is obtained using the interactive satellite data analysis software package Seadas, developed by NASA/GSFC, which includes atmospheric correction.

Chlorophyll a concentration (chl a) was estimated using the OC4 algorithm (O'Reilly et al., 5 1998).

Based on chl a image products, monthly averages and standard deviation were calculated for 2 areas matching the hydrothermal vents, with longitude and latitude ranges of $32,35^{\circ} \mathrm{W}$ $32,2166^{\circ} \mathrm{W}$ and $37,2334^{\circ} \mathrm{N}-37,3666^{\circ} \mathrm{N}$ for Lucky Strike and $33,9167^{\circ} \mathrm{W}-33,8666^{\circ} \mathrm{W}$ and $36,2167^{\circ} \mathrm{N}-36,25^{\circ} \mathrm{N}$ for Rainbow. In this study, a total of $623 \mathrm{chl}$ a image products, recorded from April 2001 to April 2003, were used to derive the monthly averages rectified of cloud and invalid pixels.

\subsection{Particle analysis}

In the laboratory, each sample from the traps was examined in toto under a dissecting microscope to sort and to count all the organisms. The shell hinge structure was examined using a Philips XL30 Scanning Electron Microscope to identify bivalve larvae (Comtet et al., 2000). Then, the remaining particles were rinsed with Milli-Q purified water ( $\mathrm{pH} \sim 7$ ), freezedried and weighed. Total sulfur, nitrogen and carbon were determined in duplicate with a Leco CNS-2000 auto-analyzer. Organic carbon concentration was measured with a Leco WR12 elemental analyzer after removing carbonates with a 2N HCl solution (Weliky et al., 1983). Inorganic carbon content was calculated as the difference between total and organic carbon. Analysis of the chemical composition of particles was undertaken by EDAX I DX-4i $\mathrm{X}$-ray spectrometry. Standards were prepared in the laboratory from pure chemical compounds. Particles and standards were strongly compressed (5 tons) to obtain a pellet of 3 $\mathrm{mm}$ in diameter with a very flat surface. The analytic accuracy was $5 \%$ for the elements with a concentration $>1 \%$.

\section{Results}

\subsection{Currents}

During the one year duration of this experiment, the current outside the vent area of Rainbow (from the "Pelagic" mooring ML2) was rather low. As usual, semi-diurnal tidal oscillations occur superimposed to a residual current. The tidal oscillations are Southwest- 
Northeast oriented with an amplitude of $\sim 10 \mathrm{~cm} \mathrm{~s}^{-1}$. Due to the changes in direction of the mean current, its mean value is only around $1 \mathrm{~cm} \mathrm{~s}^{-1}\left(\sim 0.8 \mathrm{~km} \mathrm{day}^{-1}\right)$ with a mean direction mainly to the West-Southwest (Fig. 3a).

On the contrary, near the vents, the current is highly controlled by the topography of each area. At the Rainbow site (ML1), the mean flow is steadily toward the North (Fig. 3b) which yields a mean current of $3.7 \mathrm{~cm} \mathrm{~s}^{-1}\left(\sim 3.2 \mathrm{~km} \mathrm{day}^{-1}\right)$. At the Lucky Strike site (ML3), the mean flow has a direction steadily toward the South-East (Fig. 3c) with a mean of $2.8 \mathrm{~cm} \mathrm{~s}^{-1}$ $\left(\sim 2.4 \mathrm{~km} \mathrm{day}^{-1}\right)$. At both sites, very energetic semi-diurnal tidal oscillations are also present in the Southwest- Northeast direction with an amplitude of $\sim 10 \mathrm{~cm} \mathrm{~s}^{-1}$ as at the "Pelagic" site. These semi-diurnal oscillations which are across the mean flow with a higher intensity may contribute significantly to the lateral dispersion of the material produced by the vents. Inertial oscillations also occur, mainly at Lucky Strike (period 20h).

\subsection{Temperature}

At the recording depths, temperature has long term variations which are due to the background temperature variability and depends on the depth (not shown). At the "Pelagic" mooring (ML2), the shallowest (1550 m), these variations have an amplitude of $\sim 0.7^{\circ} \mathrm{C}$ over the year. At the Rainbow site (ML1), it is only $\sim 0.1^{\circ} \mathrm{C}$ due to the greater depth (2247 $\mathrm{m}$ ). At the Lucky Strike site (ML3), at $1615 \mathrm{~m}$, it is $\sim 0.5^{\circ} \mathrm{C}$.

In addition to this long-term variability, short-term fluctuations linked to the semidiurnal internal tide are encountered throughout the year (not shown). They lie between 0.2 and $0.4^{\circ} \mathrm{C}$ at ML2 (Pelagic) and ML3 (Lucky Strike), the two shallowest levels, while they reach $0.8^{\circ} \mathrm{C}$ at ML1 (Rainbow) which is the deepest. The latter are obviously due to the hot vent influence.

\subsection{Primary production}

The satellite data of the studied area (Fig. 4) indicate that productivity remains low during the winter and increases from March-April when the spring bloom starts (max of chlorophyll: $0.3 \mathrm{mg} \mathrm{m}^{-3}$ at Rainbow and $0.7 \mathrm{mg} \mathrm{m}^{-3}$ at Lucky Strike). After April, the chlorophyll decreases rapidly and then remains low until the end of the experiment (Fig. 4). Its average concentration from April 2001 to April 2003 was 0.16 and $0.23 \mathrm{mg} \mathrm{m}^{-3}$ at Rainbow and Lucky Strike, respectively.

\subsection{Particles}


The average particle mass flux, measured away from the hydrothermal influence, was $20 \mathrm{mg} \mathrm{m}^{-2} \mathrm{~d}^{-1}$ (Fig. 5). The maximum was observed in April $2002\left(83 \mathrm{mg} \mathrm{m}^{-2} \mathrm{~d}^{-1}\right)$ corresponding to the period of the peak of surface chlorophyll concentration (Fig 4) and the minimum was measured in January $\left(0.5 \mathrm{mg} \mathrm{m}^{-2} \mathrm{~d}^{-1}\right)$. At the Rainbow field (ML-1), the average particle mass flux measured over 105 days (Fig. 5) and $10 \mathrm{~m}$ from a black smoker was equal to $471 \mathrm{mg} \mathrm{m}^{-2} \mathrm{~d}^{-1}$ (range $341-634 \mathrm{~g} \mathrm{~m}^{-2} \mathrm{~d}^{-1}$ ). High temporal variations of the mass flux were observed during the three months of the experiment with a maximum at the end of September. At the Lucky Strike area, the total mean particle mass flux from 360 days of measurement was $131 \mathrm{mg} \mathrm{m}^{-2} \mathrm{~d}^{-1}$ (range 52 to $308 \mathrm{mg} \mathrm{m}^{-2} \mathrm{~d}^{-1}$ ). The maximum was observed in April-May 2002 and the minimum in September, with a temporal variation similar to the pelagic trap.

The elemental composition of particles at the pelagic station (Table 1) was characterized by a high concentration of organic carbon and a low organic C. /N ratio ( $\approx 6)$. The organic carbon concentration varied from 3.9\% in July 01 to 10.5\% in May 02 (Fig.6). Inorganic carbon, always high (10\%), did not fluctuate throughout the year. The richness of foraminifera and diatoms in this flux confirms the mainly pelagic origin of particles sampled in this trap. The sulfur concentration was very weak and indicates the negligible hydrothermal influence in the pelagic trap.

On the contrary, the particles at the Rainbow vent were rich in sulfur and poor in organic and inorganic carbon. The main features of the Rainbow flux composition were the high concentration of iron and copper (Table 1).

At Lucky Strike, particle composition was distinguishable by the high barium concentration. Although inorganic carbon and sulfur did not vary during the year of the experiment, we observed a peak of organic carbon in June 02 (Fig.6).

\subsection{Biological particles}

The examination of samples collected in the traps revealed the presence of abundant and diversified living organisms at different stages of development (Table 2). The pelagic trap located $400 \mathrm{~m}$ a.b. is characterized by an abundant zooplankton fauna represented mainly by copepods. In the Rainbow trap, 46 shells of bivalve post larvae were sampled during the three months of the experiment and their number decreased strongly from July to October 01 (Fig. 7). The valves of the shells were well closed and these larvae were certainly alive when they were collected. Their size distribution (Fig. 8a) is particularly homogeneous (484 \pm 40 $\mu \mathrm{m}$ length of shell) and does not present a significant difference during the three months of 
the experiment (Kruskall-Wallis, $\mathrm{P}<0.05$ ). The shell sizes indicate that the post larvae are at a prodissoconch II stage. The structure of the hinge presents series of about thirty small teeth which is characteristic of mytilid bivalves and it is identical throughout the collected larvae, indicating the presence of only one species in the samples.

At Lucky Strike, the total number of bivalve larvae (83 specimens) ranged from 0 to 19 individuals per trap sampling. No characteristic trend in number of shells was observed in the trap during the year at Lucky Strike (Fig 7). Two species of bivalves were observed and the most abundant (total 70 specimens) look like the post larvae collected in the Rainbow trap, but at more varied stages of development. The distribution of shell size was from 440 to $4250 \mu \mathrm{m}$ long (Fig 8b). The second species is unknown.

Numerous polychaetes were also found in the traps close to the hydrothermal vents but fewer in the Pelagic trap (Table 2). They were essentially at postlarvae stage. Their abundance decreases strongly from July to September 01 (Fig. 7) in all the traps. After this date, the numbers of polychaetes in the Pelagic trap remains very low, with a small peak at the end of the experiment in June 02. At Lucky Strike, polychaetes were found to be more abundant throughout the year and a peak in number was observed in May 02.

Only 3 gastropods were found at Rainbow, indicating the very low density of these organisms at this station. In the Pelagic trap, the density of gastropods was also low. On the contrary, the Lucky Strike trap contained more than 200 gastropods with a maximum in November 01.

\section{Discussions}

The average total particle flux measured with the Pelagic trap positioned away from the Rainbow field was equal to $20 \mathrm{mg} \mathrm{m}^{-2} \mathrm{~d}^{-1}$. This value is higher than the particle flux obtained during about one year at the same location $\left(11 \mathrm{mg} \mathrm{m}^{-2} \mathrm{~d}^{-1}\right)$ in 1997 by Khripounoff et al. (2001) and at the Lucky Strike area in 1994 (8 $\left.\mathrm{mg} \mathrm{m}^{-2} \mathrm{~d}^{-1}\right)$ (Khripounoff et al., 2000). But these fluxes are particularly weak for the Atlantic Ocean (Auffret et al., 1996; Deuser, 1986; Khripounoff et al., 1998). Flux lower than $50 \mathrm{mg} \mathrm{m}^{-2} \mathrm{~d}^{-1}$ thus appears to characterize the oligotrophic zones of the Atlantic Ocean. The very low primary production in the Azores region observed by Angel (1989) and Strass and Woods (1991) is confirmed by our analysis of satellite images which indicates that chlorophyll concentrations were below the values obtained in the North-East Atlantic (Lampitt et al., 2001). The time variation of the particulate 
flux obtained with the Pelagic trap showed a peak of particles in April (Fig. 5). This observation is typical of temperate areas with pronounced seasonal changes in the overlying production as observed with our satellite measurements. Previous pelagic flux data obtained in the deep-sea of this region (Khripounoff et al., 2000; Khripounoff et al., 2001) indicates that the spring signal is not systematically in April in this area but can shift by more than one month in summer. The presence of the Azores front-current system which induces horizontal gradients of the distribution and the production of the primary production (Macedo et al., 2000; Schiebel et al., 2002), may explain these observed inter-annual variations. The high organic carbon concentration and the low $\mathrm{C} / \mathrm{N}$ ratio in this trap indicate the freshness of the pelagic origin particles. The very low concentration of typical hydrothermal compounds (S, $\mathrm{Fe}, \mathrm{Cu}$ ) in the particles and the absence of hydrothermal fauna confirm that the pelagic trap was not under the direct effect of the vents.

Close to the Rainbow vent, the particle flux between July and October 2001 was 30 times higher (max: $670 \mathrm{mg} \mathrm{m}^{-2} \mathrm{~d}^{-1}$ ) than that obtained on the Pelagic site. However, Khripounoff et al. (2001) observed a higher particle flux (6900 $\mathrm{mg} \mathrm{m}^{-2} \mathrm{~d}^{-1}$ ) in1997 at the same place close to this hydrothermal vent. This difference can be explained by the different distance from the trap to the vent, which was only $1 \mathrm{~m}$ in 1997 and $10 \mathrm{~m}$ during the present experiment. These results indicate the strong gradient of the hydrothermal particle sedimentation over a very short distance. Compared to the particle analysis obtained by Khripounoff et al. (2001), the particle composition also changes in relation to the distance from the emission. Ca (as CaSO4?) decreased from $23 \%$ at $1 \mathrm{~m}$ to $10 \%$ at $10 \mathrm{~m}$ and, conversely, we observed an increase in the concentrations of iron (7.2 to 22\%) and copper (5 to $8.6 \%$ ) at $10 \mathrm{~m}$. The particles sampled at Rainbow are characterized by a high Fe (Edmonds and German, 2004) and sulfur concentration produced by the hydrothermal fluid precipitation. Fig. 5 shows that the particle flux collected at Rainbow strongly fluctuated during the three months of the experiment. It was dependent on the intensity of the fluid emission and/or on the trap position relative to the vent and the current direction. Temperature anomalies (recorded by the current-meter $10 \mathrm{~m}$ above the trap) due to the hot spring were observed when the current orientation was between $270^{\circ}$ and $045^{\circ}$. The analysis for each particle sampling period of the total flux compared to the percentage of time when the current was in this direction interval (Fig. 9) indicates a good correlation between these two parameters. This result shows that the large fluctuation in the total flux can be explained only as the consequence of the current orientation and not by the variation in the spring emissions. 
At Lucky Strike, the sampled particles are distinguished by their richness in $\mathrm{Ba}(>1 \%)$ which is in agreement with the analysis of vent fluids obtained by Fouquet et al. (1994) at the same station. We also observe that the total particle flux (131 $\left.\mathrm{mg} \mathrm{m}^{-2} \mathrm{~d}^{-1}\right)$ was significantly lower than at Rainbow. Several active vents in the Atlantic, like Rainbow or TAG for example, are active black smokers which emit dark, particle-rich fluid, while the Azores shallower vents such as Lucky Strike produce translucent fluid with low particle content. These high differences in particle production result from differences in fluid chemistry which depends on the temperature and pressure conditions encountered during hydrothermal circulation (Douville et al., 1999). Phase separation events due to the shallower depth at Lucky Strike (resulting in a low metal concentration in the fluid) and the extensive alteration of the basaltic substrate explain the low particle production at these shallower stations (Klinkhammer et al., 1995; Wilson et al., 1996). Because the vent emission was low at Lucky Strike, no temperature anomalies were recorded throughout the experiment. The study of the favorable current direction from the vent to the trap was not realizable like at Rainbow. However, we observed several peaks of total particle flux between July 2001 and July 2202 (Fig. 5) but their origins are not clear. The current direction and speed did not show any differences during these peak periods and they do not seem to be responsible for the observed flux variations. However, we observe that the higher peak corresponded to the period of pelagic flux maximum. But the intensity of the particle flux from the surface in spring (83 $\mathrm{mg}$ $\left.\mathrm{m}^{-2} \mathrm{~d}^{-1}\right)$ was not enough to supply the particle flux (307 $\left.\mathrm{mg} \mathrm{m}^{-2} \mathrm{~d}^{-1}\right)$ at the same time at Lucky Strike. A local vortex as described Mullineaux et al. (2005) inducing an increase in pelagic particle flux does not seem realistic because the concentration of hydrothermal compounds such as Ba did not show a decrease during these peak periods. Variations in the fluid emission remain the best explanation for these flux peaks at this site.

The sediment trap also allows the collection of small organisms living in the vicinity of a particular environment (Khripounoff et al., 2001). In this study, we observed that the fauna sampled in the traps was diversified and abundant. Its density varied during the experiment and depended on the location of the sampling. The organisms that dominated the background pelagic flux sampled in the Pelagic sediment trap belonged essentially to zooplankton fauna. Their density fluctuated during the one year sampling duration with a maximum in July 2001 connected with the spring input of particles coming from the surface. The density of copepods in the pelagic trap is always higher than in the traps deployed at Lucky Strike and at Rainbow. However, previous studies have highlighted that zooplankton 
biomass often increases near hydrothermal fields (Herring and Dixon, 1998; Khripounoff et al., 2001; Mullineaux and France, 1995). The water nutrient enrichment, due to an abundance of free-living bacteria supporting the hydrothermal trophic food web, is the common explanation for this biomass increase (McCollom, 2000). This assertion is not confirmed by this study where plankton density and diversity in the traps moored close to the vents were lower or equal to those observed in the pelagic trap. Burd and Thomson (1995) and Burd et al. (1992) suggest that the water toxicity prevents several zooplanktonic taxa from living close to the hydrothermal chimney. It is very likely that the position of traps directly under the vent emission were unfavorable to the permanent presence of several species near the hydrothermal vents.

Other small organisms were also found in the traps moored close to the vents of Lucky Strike and Rainbow. For example, polychaete larvae were sampled in all the traps. The rapid decrease in their density in summer 2001 and then their increase in May 2002 may be indicative of a seasonal recruitment in the Azores area. Conversely, gastropods were abundant only at Lucky Strike with a maximum in autumn. Our attention was particularly drawn to bivalves because of their absence in the Pelagic trap and also the difference in size distribution between the two hydrothermal stations. In the Rainbow trap, the shells of bivalve post larvae were collected and their size distribution was very homogeneous (length $=484 \pm$ $40 \mu \mathrm{m})$. Study of their shell hinges shows that they present a series of small teeth characteristic of mytilidae, identical to the morphology of the post larvae of mytilid populations identified as Bathymodiolus azoricus at this site (Comtet et al., 2000). This result suggests that the post larvae in the traps came from the very small mussel beds observed in this hydrothermal field (Desbruyères et al., 2001). This implies that the larvae may have stayed at their natal site over a long period (3-6 weeks if we compare with the larvae development duration of the shallow mussel Mytilus edulis). The presence of bivalve larvae in the trap was certainly due to the existence of retention factors. The hydrodynamic turbulence produced by the active smokers could concentrate larvae around the trap and increase their residence time near the vent (Mullineaux and France, 1995). This mechanism would inhibit dispersal and enhance settlement in the local population (Mullineaux et al., 2005). The capture of B. azoricus always at the same stage of development over three months was surprising at Rainbow. We could expect a wider mussel stage distribution over time. This curiosity can be explained by a selective effect of the sampling equipment. Indeed, the sediment traps collect only material having the ability to settle. Therefore, the larval stage swimmers have little chance of being found in the collectors of the trap. In the same way, the post larvae, which are beginning to become fixed, do not have the possibility of being suspended by the currents and thus can no longer be collected. Finally, only the intermediate 
stage (prodissoconch stage II) between the larva swimmer and the stage already fixed would be sampled by the trap. These larvae are considered to be in the late stage of development, competent to settle and represent the new recruits (Mullineaux et al., 2005).

In the trap at Lucky Strike, the bivalves collected belonged to two different species. The most abundant had the morphology and hinges similar to the post larvae of B. azoricus collected in the Rainbow trap but at more varied stages of development. The distribution in shell size was much more heterogeneous but we did observe a significant time variation of their abundance. The characteristic of the Lucky Strike trap, rich in B. azoricus shells at different stages of development, can be explained by a novel system of transport: A great proportion of the shells observed in the trap, and mainly the largest, were fixed onto small gastropods and limpets living on the mussel beds. This new vector of transport allows post larvae and small juveniles to be present in the trap because they found a support able to re-suspend or to move. For Waren (pers com.), it seems more likely that gastropods were dislodged from the substrate and transported by water movements. This may also be supported by the fact that the Protolira species was much more common than the Lepetodrilus species in the trap, which is more firmly attached to the rocks. At Rainbow, the absence of large bivalve shells in the trap is the result of the very low density of gastropods at this site, confirmed by the only 3 animals sampled in the trap.

In this experiment, the sediment trap appears, in certain cases, to be a selective shell sorting equipment and it supports the study of mytilidae recruitment focusing the sampling on a specific stage of development. At Rainbow, the number of prodissoconch bivalves decreased significantly from July to October (Fig. 7) independently of the variations in the particle flux and the current direction. Spatial heterogeneity of the organism distribution around the vent could be the reason for this observation. However, the hypothesis of a discontinuous (seasonal?) mytilid reproduction cannot be dismissed (Comtet and Desbruyères, 1998). A previous sediment trap study at Rainbow revealed that hydrothermal bivalve larval settlement showed strong variations in summer 1997 (Khripounoff et al., 2001), like in this study. Evidence of a sexual pause, a periodicity of gametogenesis and synchronization of recruitment, have been also observed in a number of Bathymodiolus populations (see review by Tyler and Young, 1999). Recently, cage experiments developed by Colaço et al. (2006) support a main single period of spawning and of juvenile recruitment for B. azoricus collected in the hydrothermal vents of the Azores. The survival of these larvae would depend on the increase in organic particle flux sinking from the surface during the spring primary production. However, the results obtained at Lucky Strike do not allow this hypothesis to be confirmed. The density of mussel prodissoconch larvae in the trap was very low during the experiment and only one peak of mussels was observed at the end of September 2001 when the pelagic flux was particularly low. The presence of prodissoconch 
larvae throughout the year at Lucky Strike also suggests probable continuous spawning. In the light of our results, the assumption of the superposition of two reproduction strategies of the bivalves on the Azores hydrothermal vents cannot be rejected. A seasonal reproduction by the major part of the population makes it possible to synchronize the emission of gametes and to optimize recruitment. A continuous reproduction by a few animals also makes it possible to increase the chances of finding the environmental conditions the most adapted to the dispersion and the survival of the larvae.

\section{Acknowledgments}

We would like to thank the crews of the French N/O Atalante and of the Portuguese R/V Arquipelago and the ROV Victor team. We are grateful to P.-M. Sarradin (Ifremer) the chief scientist of the Atos cruise and to A. Colaço (University of the Azores), the chief scientist of the Arquipelago cruise. Satellite image recording and processing was supported by the DETRA project, funded by the Regional Directorate of Fisheries of the Azores (RAA-SRAPA/DRP-DETRA-2000-2003). This work represents part of the research program of the EU-funded VENTOX project (EVK3CT1999-00003). 
References

5 Angel, M.V., 1989. Vertical profiles of pelagic communities in the vicinity of the Azores Front and their implications to deep ocean ecology. Progress in Oceanography, 22: 146.

Auffret, G. et al., 1996. Enregistrement de l'activité hydrothermale dans les sédiments de la dorsale médio-atlantique au Sud des Açores. Comptes Rendus de l'AcadŽmie des Sciences de Paris, SŽrie II, 323: 583-590.

Burd, B.J. and Thomson, R.E., 1995. Distribution of zooplankton associated with the Endeavour Ridge hydrothermal plume. Journal of Plankton Research, 17(5): 965-997.

Burd, B.J., Thomson, R.E. and Jamieson, G.S., 1992. Composition of a deep scattering layer overlying a mid-ocean ridge hydrothermal plume. Marine Biology, 113(3): 517-526.

Cave, R.R., German, C.R., Thomson, J. and Nesbitt, R.W., 2002. Fluxes to sediments underlying the Rainbow hydrothermal plume at $36^{\circ} 14^{\prime} \mathrm{N}$ on the Mid-Atlantic Ridge. Geochimica et Cosmochimica Acta, 66: 1905-1923.

Colaço, A. et al., 2006. Annual spawning of the hydrothermal vent mussel, Bathymodiolus azoricus, under controlled aquarium, conditions at atmospgeric pressure. Journal of Experimental Marine Biology and Ecology, 333: 166-171.

Colodner, D. et al., 1993. Chemistry of the Lucky Strike hydrothermal fluids: initial results. Eos, Transactions, American Geophysical Union: 99.

Comtet, T. and Desbruyères, D., 1998. Population structure and recruitment in mytilid bivalves from the Lucky Strike and Menez Gwen hydrothermal vent areas (37 $17^{\prime} \mathrm{N}$ and $37^{\circ} 50^{\prime} \mathrm{N}$ on the Mid-Atlantic Ridge). Marine Ecology Progress Series, 163: 165177.

Comtet, T., Jollivet, D., Khripounoff, A., Segonzac, M. and Dixon, D.R., 2000. Molecular and morphological identification of Bathymodiolus azoricus (Bivalvia: Mytilidae) in situpreserved in sediment traps at Rainbow hydrothermal vent field (Mid-Atlantic Ridge). Limnology and Oceanography, 45: 1655-1661.

Desbruyères, D., Alayse, A.-M. and Antoine, E., 1994. New information on the ecology of deep-sea vent communities in the Azores Triple Junction area: Preliminary results of the Diva 2 cruise. InterRidge News, 3: 18-19.

Desbruyères, D. et al., 2001. Variations in deep-sea hydrothermal vent communities on the Mid-Atlantic Ridge when approaching the Azores plateau. Deep-Sea Research 1, 48: $1325-1346$.

Deuser, W.G., 1986. Seasonal and interannual variations in deep-water particle fluxes in the Sargasso Sea and their relation to surface hydrography. Deep-Sea Research, 33: 225246.

Douville, E. et al., 1999. Yttrium and rare earth elements in fluids from various deep-sea hydrothermal systems. Geochimica et Cosmochimica Acta, 63: 627-643.

Dymond, J. and Roth, S., 1988. Plume dispersed hydrothermal particles: A time-series record of settling flux from the Endeavour Ridge using moored sensors. Geochimica et Cosmochimica Acta, 52: 2525-2536.

Edmonds, H.N. and German, C.R., 2004. Particle geochemistry and cycling in the Rainbow hydrothermal plume. Geochimica et Cosmochimica Acta, 68: 759-772. 
Feely, R.P. et al., 1994. Composition and sedimentation of hydrothermal plume particles from North Cleft segment, Juan de Fuca Ridge. Journal of Geophysical Research, B, 99: 4985-5006.

Figueiredo, M. et al., 2004. HAZO: a software package for automated AVHRR and SeaWiFS aquisition and processing. 3, University of Azores, Horta (Azores).

Fouquet, Y., Charlou, J.-L. and Costa, I., 1994. A detailed study of the Lucky Strike hydrothermal site and discovery of a new hydrothermal site: Menez Gwen; Preliminary results of the DIVA 1 cruise. InterRidge News, 3: 14-17.

Fouquet, Y. et al., 1997. Discovery and first submersible investigations on the Rainbow hydrothermal fiel on the MAR (36 $\left.14^{\prime} \mathrm{N}\right)$. Eos, Transactions, American Geophysical Union, 78: 832.

German, C.R., Colley, S., Palmer, M.R., Khripounoff, A. and Klinkhammer, G.P., 2002. Hydrothermal plume-particle fluxes at $13^{\circ} \mathrm{N}$ on the East Pacific Rise. Deep-Sea Research 1, 49: 1921-1940.

German, C.R., Hergt, J., Palmer, M.R. and Edmond, J.M., 1999. Geochemistry of hydrothermal sediments from the OBS vent-field: $21^{\circ} \mathrm{N}$, East Pacific Rise. Chemical Geology, 155: 65-75.

Herring, P.J. and Dixon, D.R., 1998. Extensive deep-sea dispersal of postlarval shrimp from a hydrothermal vent. Deep-Sea Research, 45: 2105-2118.

Khripounoff, A. and Alberic, P., 1991. Settling of particles in hydrothermal vent field (East Pacific Rise $13^{\circ} \mathrm{N}$ ) measured with sediment traps. Deep-Sea Research, 38: 729-744.

Khripounoff, A., Comtet, T., Vangriesheim, A. and Crassous, P., 2000. Near-bottom biological and mineral particle flux in the Lucky Strike hydrothermal vent area (MidAtlantic Ridge). Journal of Marine Systems, 25: 101-118.

Khripounoff, A., Vangriesheim, A. and Crassous, P., 1998. Vertical and temporal variations of particle fluxes in the deep tropical Atlantic. Deep-Sea Research, 45: 193-216.

Khripounoff, A. et al., 2001. Particle flux in the Rainbow hydrothermal vent field (MidAtlantic Ridge): Dynamics, mineral and biological composition. Journal of Marine Research, 59: 633-656.

Kim, S.L. and Mullineaux, L.S., 1998. Distribution and near-bottom transport of larvae and other plankton at hydrothermal vents. Deep-Sea Research 2, 45: 423-440.

Kim, S.L., Mullineaux, L.S. and Helfrich, K.R., 1994. Larval dispersal via entrainment into hydrothermal vent plumes. Journal of Geophysical Research, C, 99(6): 12655-12665.

Klinkhammer, G.P., Chin, C.S., Wilson, C. and German, C.R., 1995. Venting from the MidAtlantic Ridge at $37^{\circ} 17^{\prime} \mathrm{N}$ : The Lucky Strike hydrothermal site. In: L.M. Parson, C.L. Walker and D.R. Dixon (Editors), Hydrothermal vents and processes. Geological Society, London, pp. 87-96.

Lampitt, R.S. et al., 2001. Material supply to the abyssal seafloor in the Northeast Atlantic. Progress in Oceanography, 50: 27-63.

Langmuir, C. et al., 1993. Lucky Strike: A newly discovered hydrothermal site on the Azores platform. RIDGE Events, 4: 3-5.

Macedo, M.F., Duarte, P., Ferreira, J.G., Alves, M. and Costa, V., 2000. Analysis of the deep chlorophyll maximum across the Azores Front. Hydrobiologia, 441: 155-172.

McCollom, T.M., 2000. Geochemical constraints on primary productivity in submarine hydrothermal vent plumes. Deep-Sea Research 1, 47: 85-101.

Metaxas, A., 2004. Spatial and temporal patterns in larval supply at hydrothermal vents in the northeast Pacific OceanLimnology and Oceanography. Limnology and Oceanography, 49: 1949-1956.

Mullineaux, L.S. and France, S.C., 1995. Dispersal mechanisms of deep-sea hydrothermal vent fauna. In: S.E. Humphris, R.A. Zierenberg, L.S. Mullineaux and R.E. Thomson 
(Editors), Seafloor hydrothermal systems: physical, chemical, biological, and geological interactions. American Geophysical Union, Washington, pp. 408-424.

Mullineaux, L.S. et al., 2005. Vertical, lateral and temporal structure in larval distributions at hydrothermal vents. Marine Ecology Progress Series, 293: 1-16.

Mullineaux, L.S., Wiebe, P.H. and Baker, E.T., 1995. Larvae of benthic invertebrates in hydrothermal vent plumes over Juan de Fuca Ridge. Marine Biology, 122: 585-596.

O'Reilly, J.E. et al., 1998. Ocean color chlorophyll algorithms for SeaWiFS. Journal of Geophysical Research, C, 24: 24937-24954.

Schiebel, R., Waniek, J., Zeltner, A. and Alves, M., 2002. Impact of the Azores Front on the ditribution of planktic foraminifers, shelled gastropods and coccolithophorids. DeepSea Research 2, 49: 4035-4050.

Strass, V.H. and Woods, J.D., 1991. New production in the summer revealed by the meridional slope of the deep chlorophyll maximum. Deep-Sea Research, 38: 35-56.

Tyler, P.A. and Young, C.M., 1999. Reproduction and dispersal at vents and cold seeps. Journal of the Marine Biological Association of the U. K., 79: 193-208.

Van Dover, C.L. et al., 1996. Biology of the Lucky Strike hydothermal field. Deep-Sea Research I, 43(9): 1509-1529.

Weliky, K., Suess, E., Ungere, C., Muller, P. and Fischer, K., 1983. Problems with accurate carbon measurements in marine sediments and water column particulates: a new approach. Limnology and Oceanography, 28: 1252-1259.

Wilson, C. et al., 1996. Hydrothermal anomalies in the Lucky Strike segment on the MidAtlantic Ridge (37 $\left.17^{\prime} \mathrm{N}\right)$. Earth and Planetary Science Letters, 142: 467-477. 


\begin{tabular}{lccc}
\hline \multicolumn{1}{c}{$\%$} & $\begin{array}{c}\text { PELAGIC } \\
\text { (360 days) }\end{array}$ & $\begin{array}{c}\text { RAINBOW } \\
\text { (105 days) }\end{array}$ & $\begin{array}{c}\text { LUCKY STRIKE } \\
\text { (360 days) }\end{array}$ \\
\hline Organic C. & 7.42 & 1.46 & 3.59 \\
Inorganic C. & 9.59 & 2.05 & 5.87 \\
Nitrogen & 1.16 & 0.16 & 0.64 \\
$\mathrm{Mg}$ & 0.99 & 0.51 & 0.88 \\
$\mathrm{Al}$ & 1.56 & 1.33 & 1.69 \\
$\mathrm{Si}$ & 8.745 & 3.24 & 6.29 \\
$\mathrm{P}$ & 0.51 & 1.32 & 0.74 \\
$\mathrm{~S}$ & 0.99 & 16.49 & 3.35 \\
$\mathrm{~K}$ & 0.445 & 0.21 & 0.31 \\
$\mathrm{Ca}$ & 26.49 & 10.28 & 20.88 \\
$\mathrm{Ba}$ & 0.28 & 0.36 & 1.20 \\
$\mathrm{Mn}$ & 0.13 & 0.16 & 0.39 \\
$\mathrm{Fe}$ & 0.53 & 22.18 & 8.98 \\
$\mathrm{Cu}$ & 0.14 & 8.63 & 0.53 \\
$\mathrm{Zn}$ & 0.12 & 0.95 & 0.30 \\
\hline
\end{tabular}

Table 1: Mean elemental composition (\%) of particles sampled in the traps 


\begin{tabular}{llll}
\hline & $\begin{array}{l}\text { Pelagic } \\
\text { (360 days) }\end{array}$ & $\begin{array}{l}\text { Rainbow } \\
\text { (105 days) }\end{array}$ & $\begin{array}{l}\text { Lucky Strike } \\
\text { (360 days) }\end{array}$ \\
\hline Bivalves & 0 & 46 & 103 \\
Polychaetes & 90 & 127 & 282 \\
Gastropods & 32 & 3 & 222 \\
Isopods & 7 & 10 & 29 \\
Amphipods & 261 & 3 & 46 \\
Copepods & 801 & 167 & 150 \\
Ostracods & 59 & 2 & 107 \\
Euphausiids & 45 & 0 & 37 \\
\hline
\end{tabular}

Table 2: Biological composition of particles from the different traps (Experiment duration of 360 days for Pelagic and Lucky Strike and 105 days for Rainbow) 
Figure captions

Figure 1: Bathymetric maps of the Rainbow and Lucky Strike sites with the positions of the different moorings and the active hydrothermal vents.

Figure 2: Sediment trap (a) and long-term mooring (b) used close to each hydrothermal vent station.

Figure 3: Progressive vector diagrams showing currents recorded at the three mooring locations at the ATJ: Pelagic (a), Rainbow (b) and Lucky Strike (c).

Figure 4: Monthly average chlorophyll concentration determined at the sea surface above the hydrothermal stations, from satellite images.

Figure 5: Temporal variations of total particle flux measured with sediment traps positioned far from and close to the hydrothermal vents.

Figure 6: Temporal variation of the particle composition collected in the sediment traps. (a) Organic carbon, (b) Inorganic carbon, (c) Sulfur.

Figure 7: Time variation of the bivalve (only the prochisoconch stage is taken into consideration in this figure), polychaete and gastropod abundances in the Rainbow, Lucky Strike and Pelagic traps

Figure 8: Size of the bivalve larvae shells collected in the sediment trap at Rainbow (a) and Lucky Strike (b) stations.

Figure 9: Total particle flux and percentage of current in the $270^{\circ}-045^{\circ}$ direction during each sample near the Rainbow vent site. 


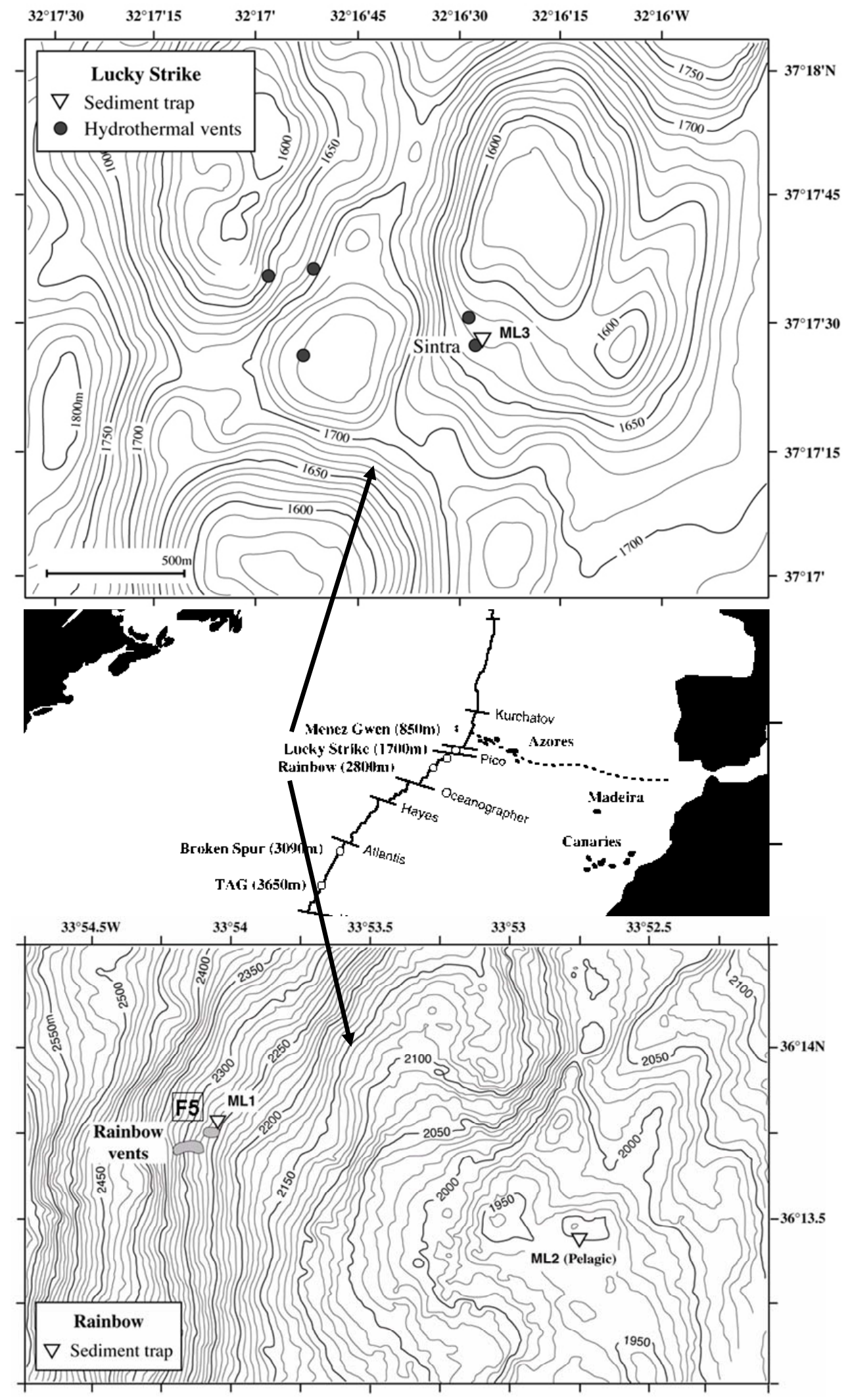

Figure 1: Bathymetric maps of the Rainbow and Lucky Strike sites with the positions of the different moorings and the active hydrothermal vents. 

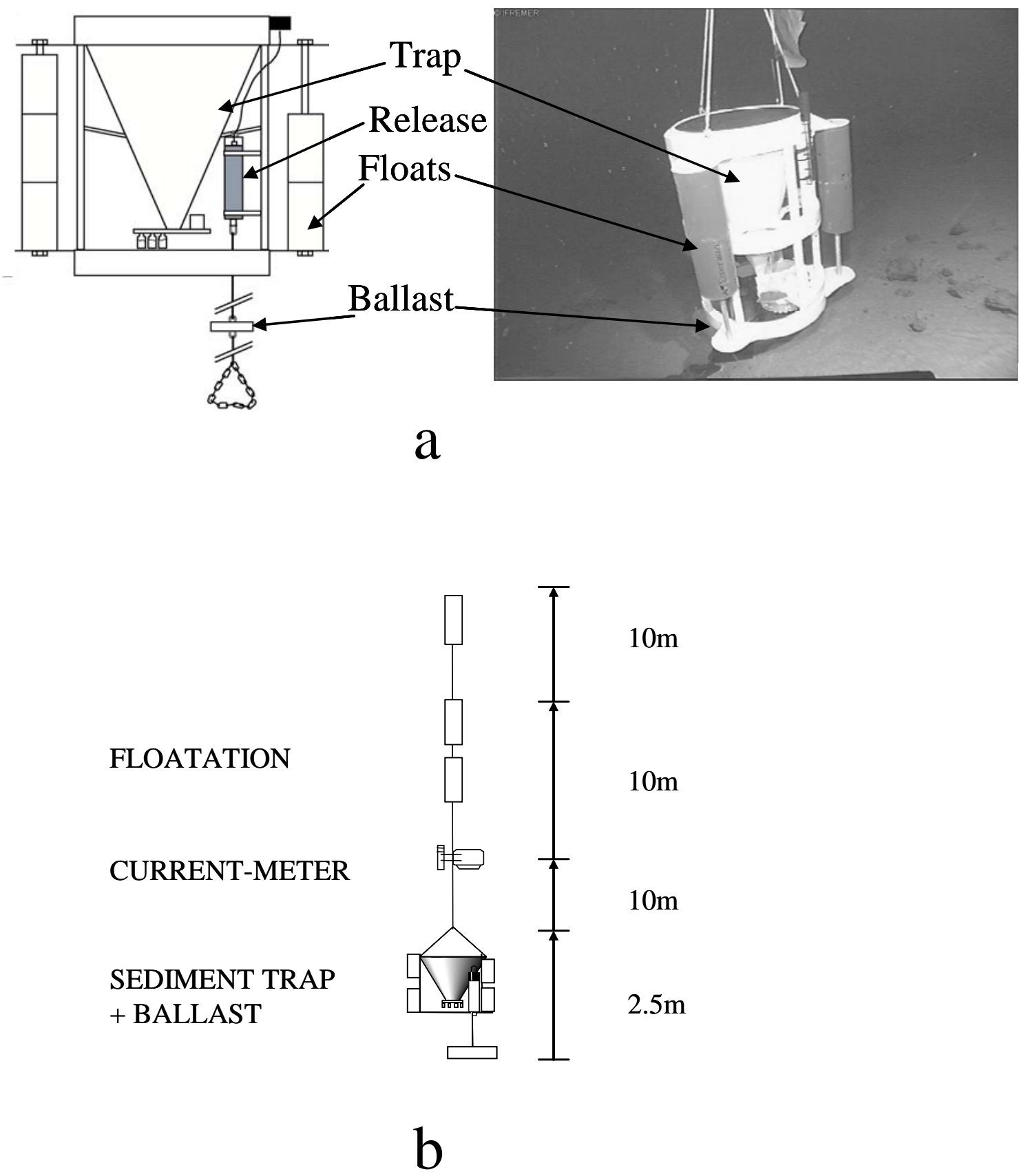

Figure 2: Sediment trap (a) and long-term mooring (b) used close to each hydrothermal vent station. 

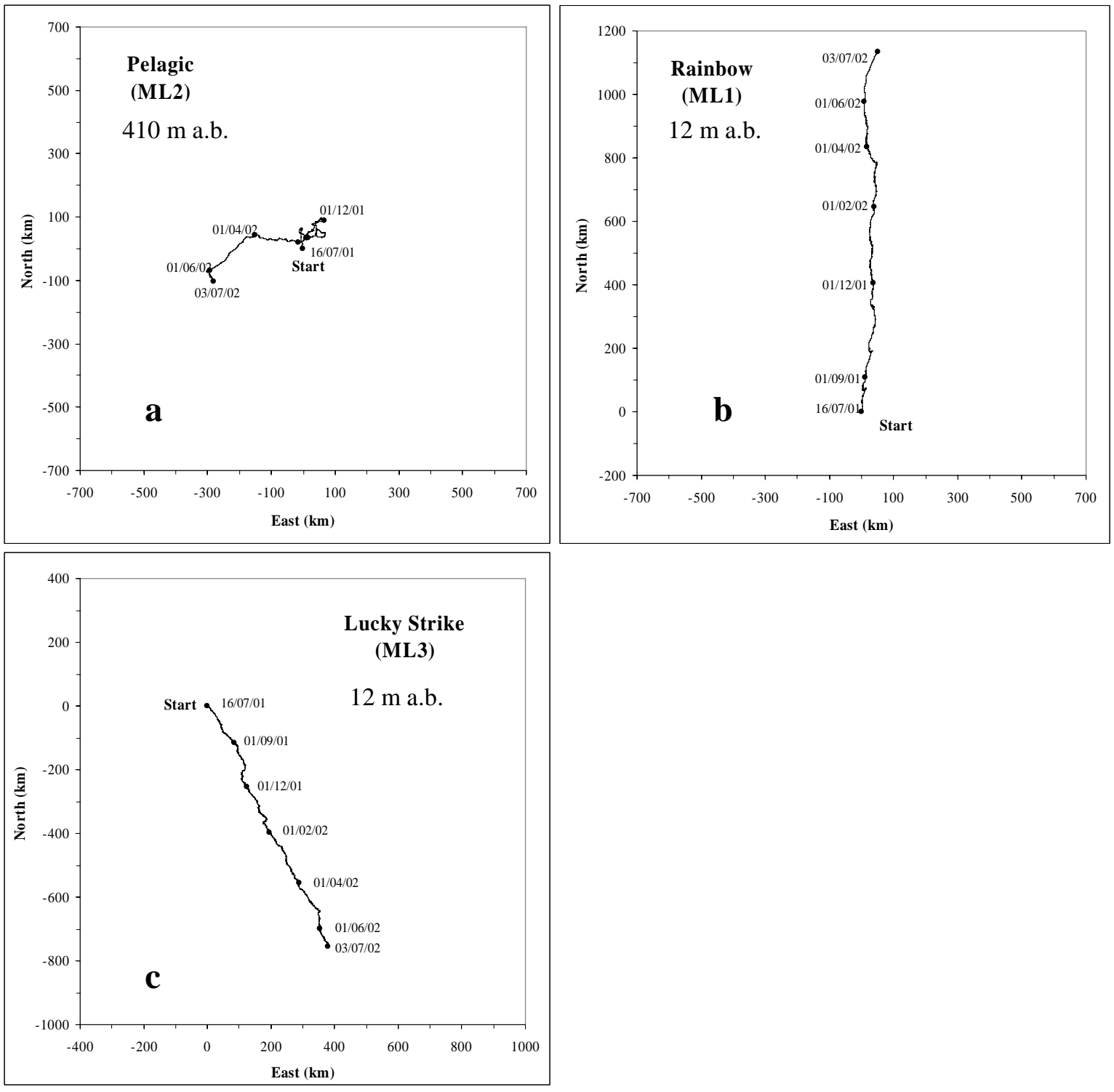

Figure 3: Progressive vector diagrams showing currents recorded at the three mooring locations at the ATJ: Pelagic (a), Rainbow (b) and Lucky Strike (c). 


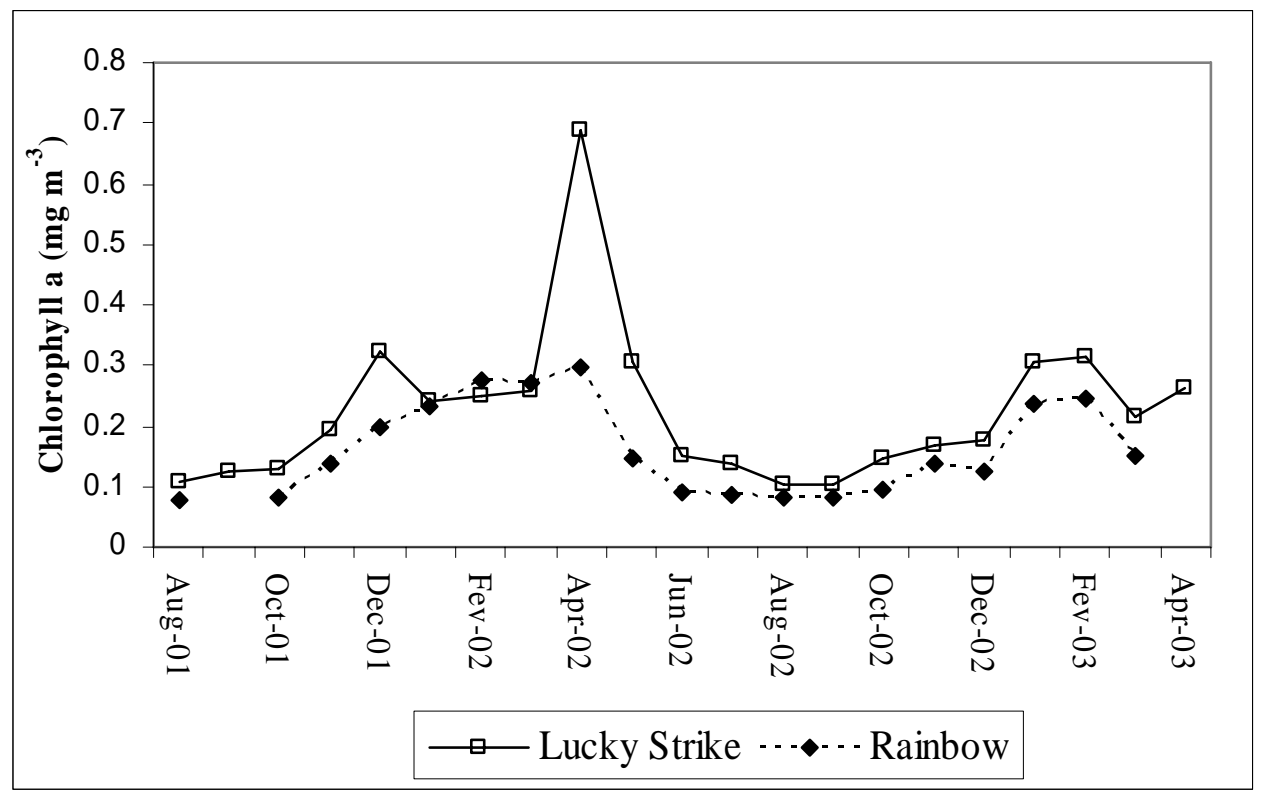

Figure 4: Monthly average chlorophyll concentration determined at the sea surface above the hydrothermal stations, from satellite images. 


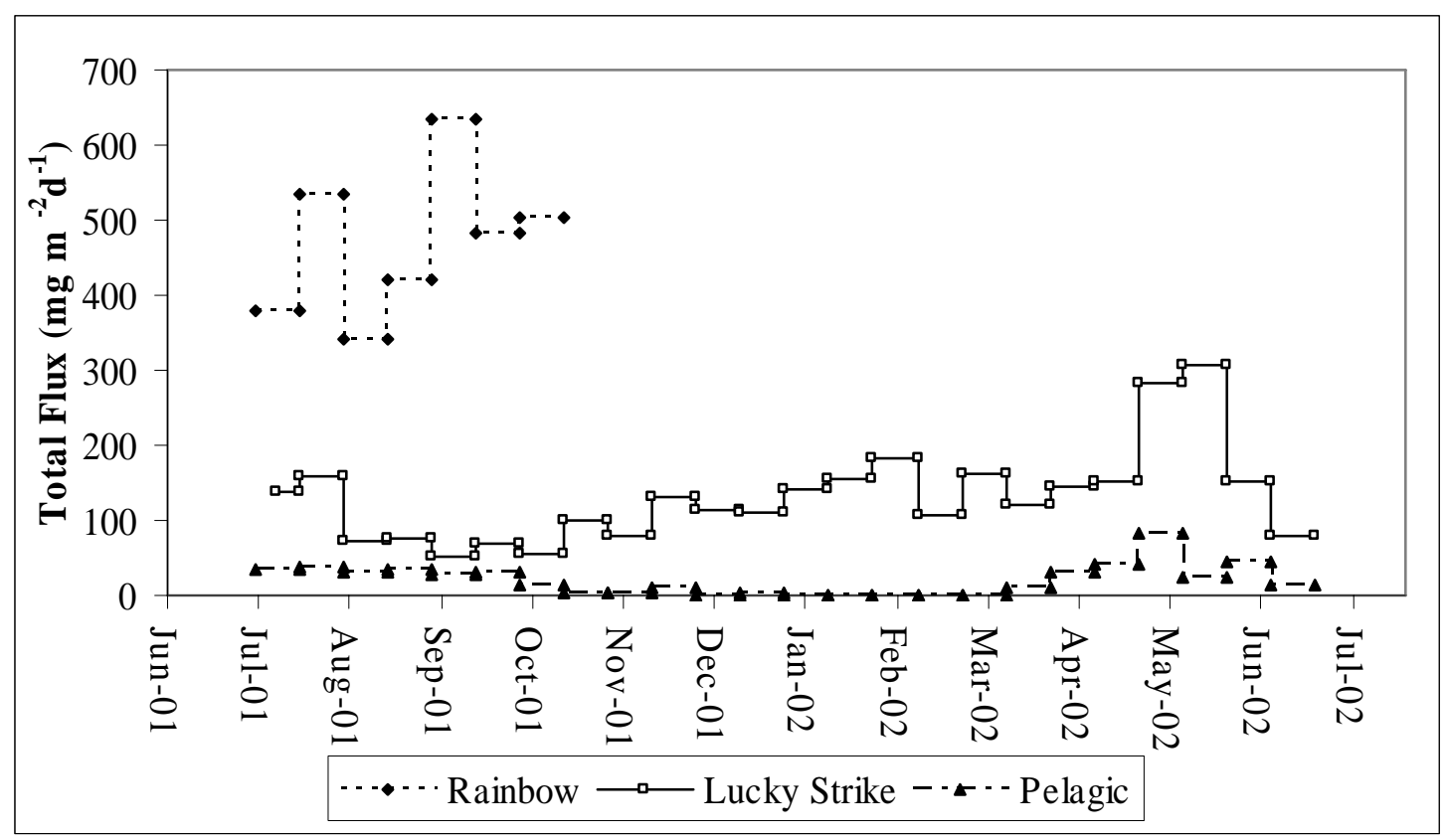

Figure 5: Temporal variations of total particle flux measured with sediment traps positioned far from and close to the hydrothermal vents. 

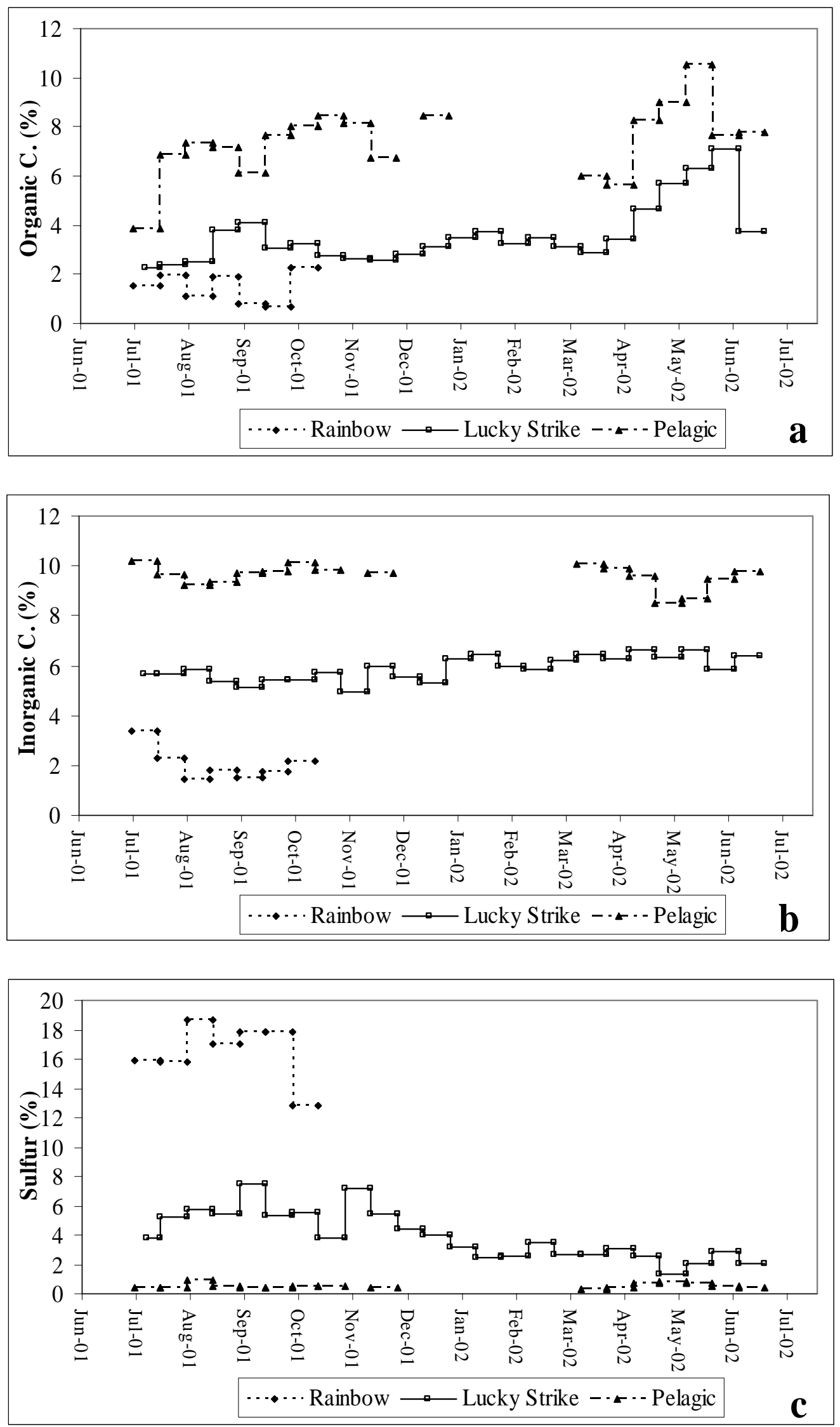

Figure 6: Temporal variation of the particle composition collected in the sediment traps. (a) Organic carbon, (b) Inorganic carbon, (c) Sulfur. 

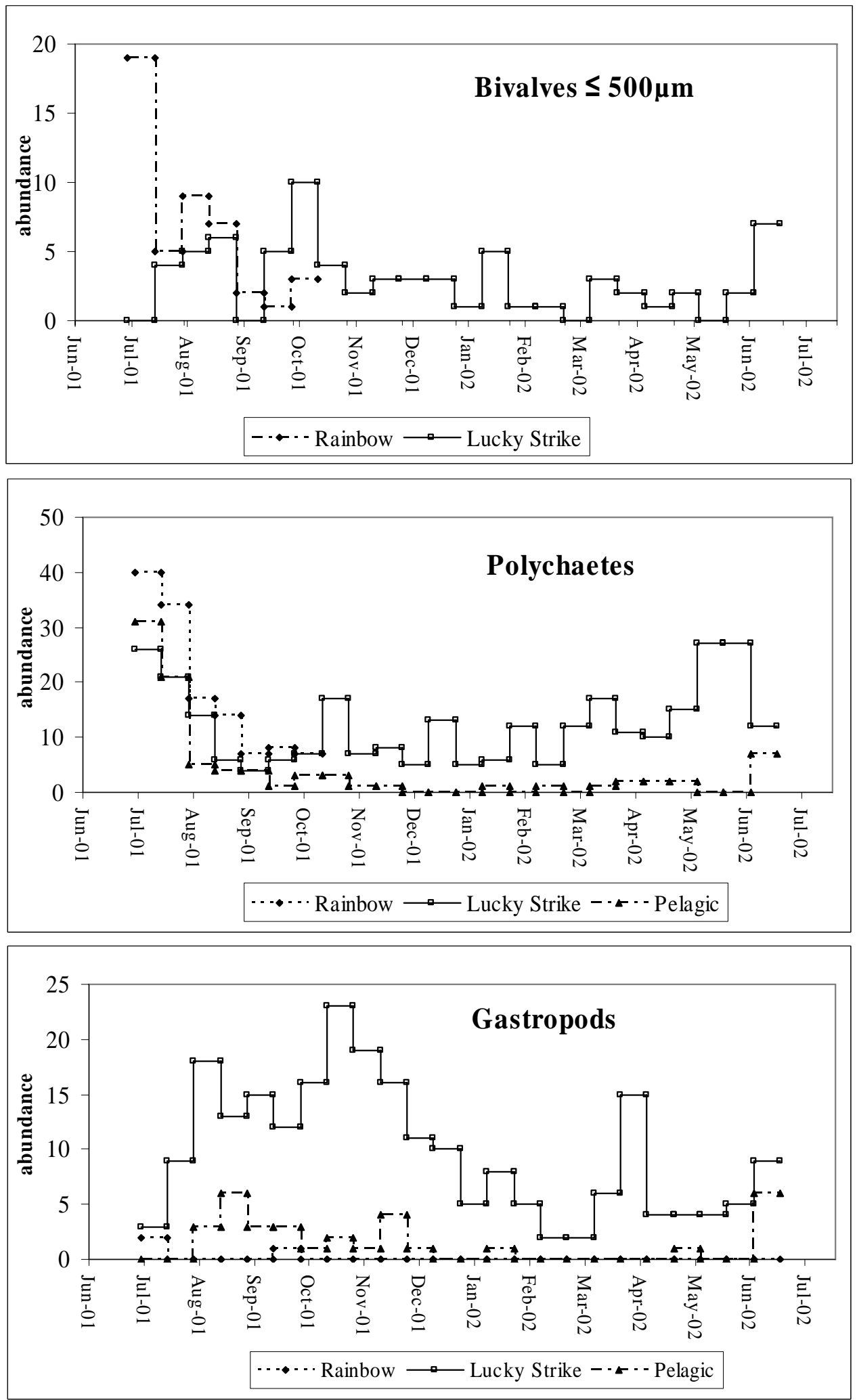

Figure 7: Time variation of the bivalve (only the prochisoconch stage is taken into consideration in this figure), polychaete and gastropod abundances in the Rainbow, Lucky Strike and Pelagic traps 


\section{Rainbow}

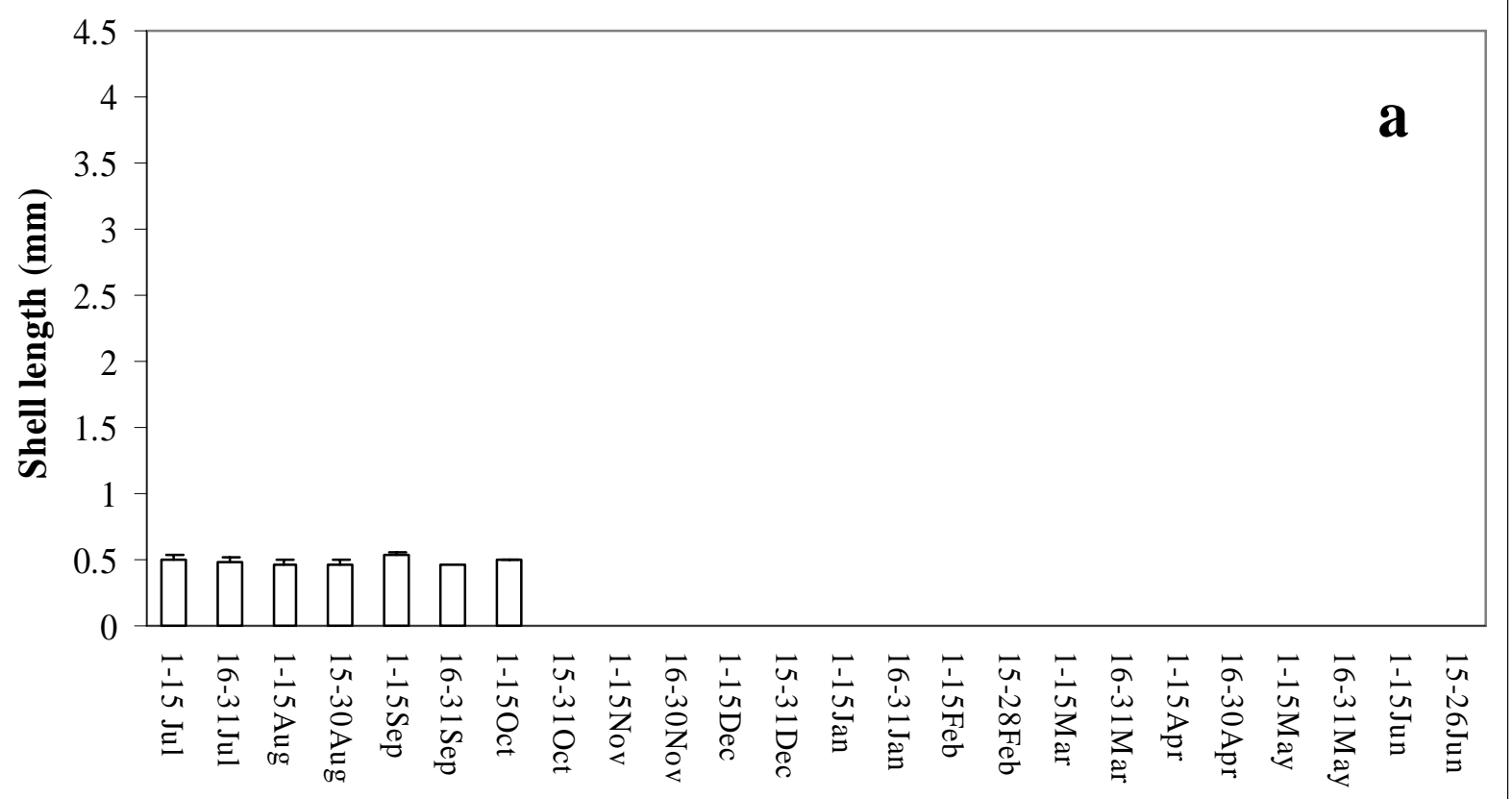

\section{Lucky Strike}

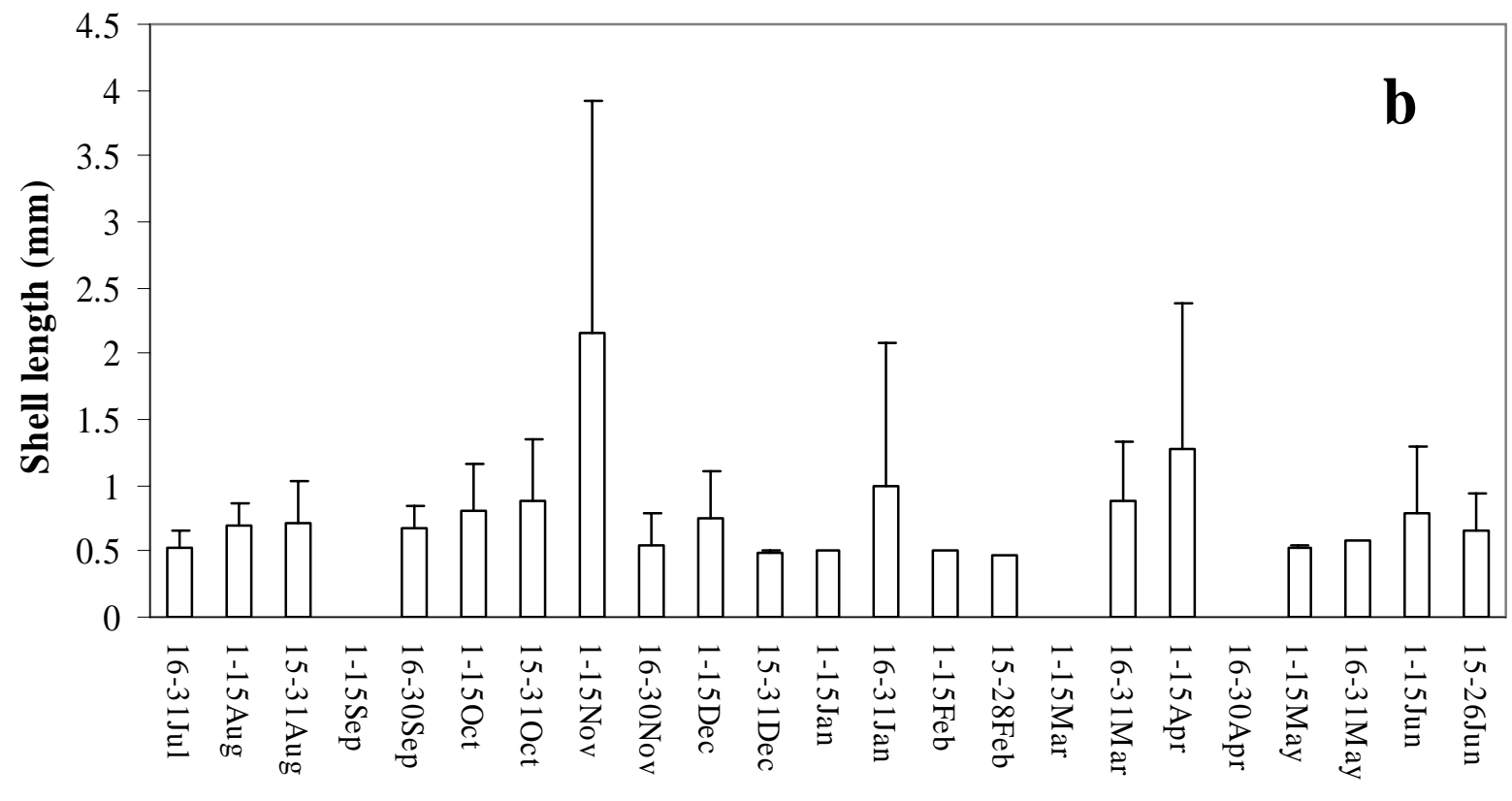

Figure 8: Size of the bivalve larvae shells collected in the sediment trap at Rainbow (a) and Lucky Strike (b) stations. 


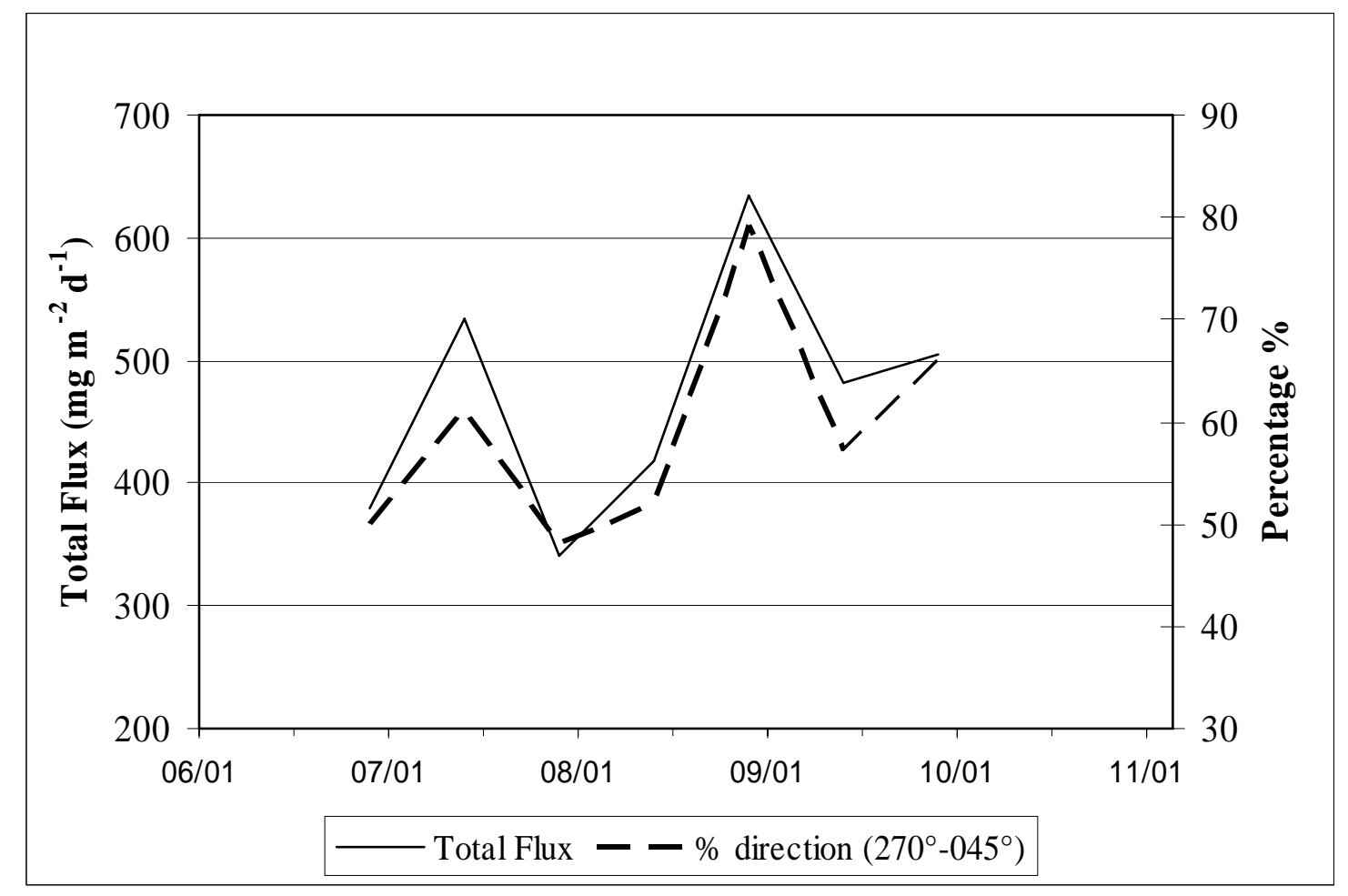

Figure 9: Total particle flux and percentage of current in the $270^{\circ}-045^{\circ}$ direction during each sample near the Rainbow vent site. 